\title{
Penyelesaian Kejahatan \\ yang Termasuk "White Collar Crime"
}

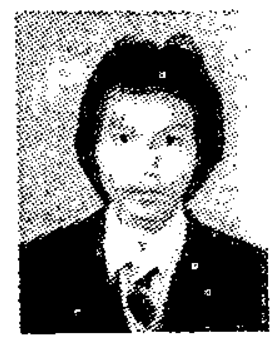

Mudzakkir

Di antara yang menjadikan semakin menariknya perbincangan seputar WCC adalah adanya KUHP yang dinilai belum bisa mencover bentuk kejahatan ini. Untuk itu, Mudzakkir menawarkan "musyawarah (cooperation)" sebagai alternatif penyelesaian.

\section{Pendahuluan}

SALAH satu gelagat kejahatan yang terjadi sehubungan dengan perkembangan dalam bidang ekonomi akhir-akhir ini adalah munculnya kejahatan yang oleh kalangan sosiolog dan kriminolog dikenal dengan "Whitecollar crime". ${ }^{1}$ Istilah ini muncul sebenarnya bukan dimaksudkan untuk mencari nama pada bentuk perbuatan pidana baru, ${ }^{2}$ melainkan sekedar untuk mengkategorisasikan terhadap perbuatan pidana yang pelakunya memiliki ciri-ciri tersendiri. Dengan kata lain, tidak ada peraturan hukum baru yang secara langsung memberi penamaan (kualifikasi) sendiri sebagai "white-collar-crime", seperti halnya perbuatan pidana korupsi.

Dalam literatur kriminologi dikenal dengan berbagai macam istilah yang ditujukan kepada pelanggaran hukum pidana, misalnya "Street Crime" atau "Underwold Crime", istilah ini ditujukan pada kejahatan yang terjadi dalam masyarakat dan dilakukan secara konvensional atau dilakukan oleh orang-orang yang status sosialnya rendah atau golongan bawah, "Organized Crime" atau "Corporate Crime", istilah ini ditujukan untuk kejahatan yang dilakukan oleh pelaku yang terorganisasi atau korporasi (badan hukum) -- bukan oieh kelompok orang semata. Sedangkan istilah "white-collar crime" ditujukan terhadap kejahatan yang dilakukan oleh orang-orang yang terhormat atau memiliki status sosial menengah ke atas (upperwold crime). Secara kasar Gilbert Geist mengatakan bahwa "white-collar crime" padanan dari "upperwold crime" untuk menunjukkan perbedaannya dengan "under- wold crime". 3

Penamaan bentuk pelanggaran hukum pidana menjadi "white-collar crime" dan lainnya tersebut dilatar-belakangi oleh karakteristik pelaku kejahatan beserta akibatakibatnya. Karena pelaku kejahatan memiliki sifat-sifat yang khas sehingga kejahatan ini menjadi menarik perhatian. Ada beberapa hal 
yang dapat dijadikan alasan perhatian terhadap WCC:

Pertama, adanya paradigma baru dalam memahami kausa kejahatan. Dengan adanya WCC ini menegaskan teori sebelumnya yang diyakini kebenarannya bahwa kemiskinan sebagai penyebab terjadinya kejahatan. Orang miskin sebagai golongan masyarakat yang ditempatkan sebagai "underwold crime" sering dituduh sebagai "conditio sine qua non" berbagai macam penyimpangan sosial. Dengan adanya pengakuan terhadap bentuk pelanggaran yang termasuk WCC yang umumnya dilakukan oleh golongan masyarakat yang terhormat dan terpandang -- oleh karenanya disebut juga "upperwold crime" -- merupakan bukti adanya paradigma baru dalam melihat perilaku kejahatan. Kesimpulan tersebut sekaligus merupakan revisi terhadap pandangan yang dangkal dan 'picik' dalam menganalisis tindak kejahatan.

Kedua, memperluas pelaku (subjek) kejahatan. Kejahatan hanya dapat dilakukan oleh subjek hukum orang ternyata tidak sepenuhnya mampu menjangkau permasalahan yang dihadapi akibat percepatan laju perkembangan ekonomi. Dalam prakteknya, pelanggaran hukum pidana dapat juga dilakukan oleh subjek hukum, badan hukum atau korporasi. Adanya perluasan subjek hukum ini membuka peluang terjadinya bentuk-bentuk baru pelanggaran hukum pidana yang sebelumnya tidak dipandang sebagai suatu perbuatan yang dapat dipidana.

Ketiga, perluasan terhadap pengertian kejahatan. Adanya kemajuan dalam sektor ekonomi dan sektor kehidupan lainnya berpengaruh timbal-balik terhadap hukum pidana. Pengaruh timbal-balik tersebut ditandai dengan adanya pelarangan terhadap perbuatan yang semula tidak dilarang (kriminalisasi) dan perluasan perbuatan yang dapat dipidana (penalisasi) atau dengan menggunakan metodologi hukum untuk memperluas daya jangkau berlakunya hukum pidana merupakan ciri dan konsekuensi logis dari sistem hukum pidana yang mengikuti asas legalitas.
Disadari sepenuhnya bahwa kajian terhadap bentuk perilaku kejahatan yang termasuk "white-collar crime" untuk memperoleh hasil yang lengkap dan mendalam adalah sulit untuk dilakukan karena terkait dengan beberapa variabel sosial yang kompleks sifatnya. Cepatnya laju perkembangan berbagai bidang kehidupan sosial tersebut sering menjadi faktor yang mengharuskan adanya pengkonsepan ulang terhadap kesimpulan-kesimpulan teoritis kajian terhadap kejahatan, hukum pidana, dan penegakan hukum pidana. Tulisan ini tidak bermaksud mengkaji WCC secara komprehensif, melainkan hanya mendeskripsikan bentuk penyelesaian kejahatan yang dikategorikan sebagai "white-collar crime" beserta kendalakendalanya.

\section{"White-Collar Crime" dan "Organized Crime"}

UNTUK Mengkaji bagaimana penyelesaian kejahatan yang termasuk kategori "white-collar crime" pertama-tama harus mengetahui lebih dahulu tentang perilaku pelanggaran hukum pidana tersebut. Latar-belakang perilaku pelanggar hukum pidana pada dasarnya bukan menjadi titik perhatian ilmu hukum pidana, melainkan menjadi objek kajian ilmu sosial, kriminologi, dan cabang ilmu sosial lainnya. Fokus perhatian ilmu hukum pidana adalah pada peraturan-peraturan yang mengatur tentang perbuatan-perbuatan apa yang dilarang (kejahatan) dan yang bertalian dengan pidana.

Tipologi pelanggaran hukum pidana, menurut kajian ilmu sosial dan kriminologi, dapat diklasifikasikan dalam berbagai macam tipologi. Tipologi kejahatan dilihat perbuatannya dikelompokkan menjadi kejahatan yang dilakukan dengan kekerasan, kejahatan yang dilakukan secara profesional, "white-collar crime", kejahatan yang ditujukan pada hartabenda, kejahatan yang terorganisasi, dan kejahatan politik. ${ }^{6}$ Larry J. Siegel membagi tipologi kejahatan menjadi kejahatan kekerasan, kejahatan di bidang ekonomi yang termasuk "street crime", kejahatan di bidang ekonomi yang terorganisasi yang meliputi "white-collar crime" dan "organized crime", dan kejahatan yang melanggar ketertiban umum (publik 
order). ${ }^{7}$ Ditinjau dari sudut subjek atau pelaku kejahatan dibedakan antara kejahatan yang dilakukan orang sebagai individu dan dilakukan oleh badan hukum atau korporasi (coorporate crime).

Penggolongan kejahatan menjadi berbagai golongan tersebut tidak selamanya dapat dijadikan alat analisis secara tepat untuk menjelaskan fenomena sosial kejahatan yang terjadi dalam masyarakat. 'Perkembangan' kejahatan merupakan instrumen perkembangan sosial dan merupakan sintesa dan antitesa -- secara negatif -- terhadap perkembangan sosial tersebut. Dalam kaitannya dengan itu, pembentuk undang-undang (legislatif) dan penegak hukum harus mencermati dan mengantisipasi gelagat perkembangan berbagai sektor kehidupan masyarakat tersebut. Karena, pada sisi lain, para calon pelanggar selalu mencari peluang di celah-celah usaha legislatif dan penegak hukum dalam menutup peluang pelanggaran terhadap hukum pidana. Artinya pembentuk undangundang dan penegak hukum dituntut untuk memiliki kemampuan deteksi secara dini terhadap dampak sosial yang akan terjadi sehubungan dengan adanya perkembangan tersebut.

Kemajuan dalam bidang perekonomian, misalnya, membawa dampak negatif terhadap masyarakat. Masyarakat selalu menjadi sasaran (target) dari perilaku para pelaku ekonomi dalam rangka untuk mencari keuntungan yang sebesar-besarnya sebagai bagian dari prinsip ekonomi. Tidak jarang untuk mencapai keuntungan tersebut para pelaku ekonomi secara sendiri-sendiri atau bersama-sama melakukan perbuatan melanggar hukum. Sedangkan bentuk-bentuk pelanggaran hukum pidana (kejahatan) di bidang kegiatan ekonomi menurut Siegel ${ }^{8}$ dibedakan menjadi dua, yaitu "whitecollar crime" dan "organized crime" (OC).

Kedua bentuk kejahatan tersebut sering dianggap sama karena keduanya dilakukan oleh orang yang memiliki status sosial menengah ke atas, maka keduanya sering disebut "upperwold crime". Ciri yang menonjol dari kejahatan ini adalah pelanggaran hukum (pidana) yang mengatur kegiatan ekonomi. WCC diartikan sebagai "the illegal activities of people and institutions whose acknowledged pupose is profit and gain through legitime business transactions." Sedang "organized crime" diartikan sebagai "the illegal activity of people and organizations whose acknowledged purpose is illegitimate gain through illegal enterprise." Dalam kaitannya dengan bentuk pelanggarannya, "organized crime" disinonimkan dengan "corporate crime".

Berbeda dengan Siegel, Cilenart dan Yeager berpendapat bahwa "organized crime" merupakan bagian dari WCC. Perbuatan WCC dibedakan menjadi dua bentuk, yaitu yang dilakukan oleh individu yang menyalah-gunakan jabatan, termasuk kejahatan jabatan, dan kejahatan organisasi. ${ }^{10}$ Kejahatan jabatan dilakukan oleh perorangan dalam hubungannya dengan jabatannya dalam rangka untuk memperoleh keuntungan dirinya, sedang kejahatan organisasi yang juga disebut kejahatan korporasi adalah kejahatan yang dilakukan oleh perusahaan-perusahaan, pegawai-pegawai, dan agen-agennya terutama untuk memajukan tujuan-tujuan sah organisasi yang dilakukan secara illegal, misalnya sepakat menetapkan harga, menyuap petugas bukum, dan menyalah-gunakan alat timbang.

Bentuk-bentuk kejahatan yang termasuk kategori WCC dan OC pada umumnya merupakan bentuk-bentuk kejahatan yang telah diatur dalam peraturan hukum (pidana). Ada beberapa bentuk perbuatan WCC yang sulit untuk dikategorikan sebagai perbuatan pelanggaran hukum pidana yang sebenarnya (pelanggaran hukum pidana yang semu), karena masyarakat umum tidak merasakan langsung bahwa perbuatan itu sebenarnya merupakan perbuatan yang melawan hukum yang dapat diancam dengan pidana, apalagi perbuatan tersebut dilakukan oleh anggota masyarakat yang tergolong terhormat atau terpandang dan terorganisasi.

\section{Reaksi Terhadap WCC}

MASYARAKAT sulit untuk mengindentifisir perbuatan yang tergolong WCC. Kejahatan ini terjadi kadang-kadang melalui suatu proses yang cukup lama dan secara diam-diam 
-- karena ketidak-tahuannya -- masyarakat 'menerima' perlakuan tersebut atau tidak memberikan reaksi terhadapnya, seperti halnya reaksi yang diberikan kepada kejahatan biasa. Sikap pasif masyarakat tersebut menciptakan situasi yang kriminogen dan viktimogen.

Sikap pasif masyarakat dan belum adanya kemauan politik penegak hukum tersebut disebabkan karena sulit mendeteksi perilaku pelanggar, korban , dan akibat/kerugian yang ditimbulkan semu. Kerugian yang diakibatkan oleh. kejahatan yang termasuk ,WCC sebenarnya sangat besar dan dalam skala yang luas serta. sulit ditentukan batas-batasnya yang dapat diderita oleh individu, masyarakat, organisasi/institusi, dan negara. Kerugiăn yang ditimbulkan oleh WCC tidak dirasakan secara langsung oleh korban seperti halnya kejahatan kekerasan - kadangkala masyarakat jus tru menganggap bahwa perbuatan yang dilakukan olé WCC tidak dipandang sebagai kategori kejahatan yang lebih serius daripada kejahatan , biasa yang dilakukan secara konvensional.

Reaksi masyarakat -- demikian juga penegak hukum -- terhadap WCC kurang memiliki "daya tekan" dan" cenderung tidak kritis disebabkan oleh beberapa faktor: pertama, pelakunya sering dianggap sebagai pelanggar yang tidak membahayakan atau tidak mengancam secara langsung terhadap ketertiban dan keamanan umum; kedua, tidak dianggap sebagai kejahatan yang serius; ketiga, hakim dan aparat penegak hukum lainnya menganggap WCC adalah bukan kejahatan yang sebenarnya (real criminal) oleh karenanya jarang diproses dan dijatuhi pidana; keempat, anggapan umum bahwa penangkapan merupakan tindakan yang sangat memalukan dan pemidanaan dinilai sebagai tindakan tidak bermanfaat untuk menyelesaikan kejahatan yang termasuk WCC; kelima, adanya sikap "ambiguity" terhadap pelaku kejahatan dan perbuatannya.

Perlakuan yang 'istimewa' terhadap pelanggar hukum pidana yang termasuk WCC, di samping disebabkan oleh faktor-faktor tersebut di atas, dapat bersumber dari peraturan hukum pidana itu sendiri. Sebagian besar bentuk perbuatan : pidana yang diatur dalam berbagai peraturan hukum pidana yang tersebar di luar KUHP sudah diatur dalam KUHP. Jika terjadi pelanggaran, penegak hukum dapat memilih antara mendakwa dengan pasal dalam KUHP atau di luar ,KUHP, padahal perbuatannya adalah sama tapi dilakukan oleh pelaku yang memiliki status yang berbeda. Misalnya, pencurian listik yang dilakukan individu untuk kebutuhan rumah-tangga dengan perusahaan untuk produksi. Golongan pertama sering dituduh mencuri (Pasal 362 , KUHP) sedang, golongan kedua dituduh melakukan perbuatan korupsi , (WCC), Dengan tuduhan korupsi tersebut menunjukkan bahaya dan beratnya ancaman pidana, tetapi di sisi lain dengan túduhan korupsi tersebut memberi peluang terdakwa untuk menegosiasikan pelanggarannya dengan cara menghilangkan salah satu unsur sifat melawan hukumnya perbuatan korupsi, yaitu merugikan keuangan negara dengan cara membayar tagihan kepada PLN.

Penggolongan pelanggar hukum -pidana secara 'diskriminatif' tersebut dapat menimbulkan akibat yang tidak menguntungkan terhadap proses penegakan hukum itu sendiri. Dalam prakteknya, adanya stigmatisasi terhadap calon pelanggar justru menjadi daya tangkal sendiri terhadap masyarakat. Jika kekuatan stigma dikurangi dengan cara memperhalus istilah (eufimisme) maka daya pengaruh tersebut akan berkurang. Dalam perkembangannya, ada kecenderungan untuk menafsirkan secara luas pengertian WCC, yaitu mencakup jabatan yang tidak menunjukkan status sosial yang tinggi saja. Newman ${ }^{11}$, misalnya, menyatakan bahwa seharusnya pekerjaan petani, tukang reparasi yang bukan pekerjaan WCC dapat melakukan pelanggaran yang dapat dikategorikan sebagai WCC, misalnya mencampur susu dengan air, tukang reparasi yang mengganti alat yang seharusnya tidak perlu diganti, petugas pompa bensin yang merusak atau mengubah alat pengukur/meteran.

Stigmatisasi pelanggar hukum sering dikritik sebagai suatu tindakan yang negatif dalam kaitannya dengan program pemasyarakatan terpidana. Sungguh pun demikian, dalam -ke- 
bijakan kriminal stigmatisasi diperlukan, karena mempunyai daya pengaruh yang efektif dalam rangka prevensi kejahatan. Gejala eufimisme terhadap perbuatan pelanggaran hukum pidana sejauh mungkin harus dihindari. Stigmatisasi terhadap pelanggar hukum pidana melalui konstruksi penyusunan peraturan hukum pidana yang dapat menjangkau berbagai perbuatan yang dilakukan oleh masyarakat dari berbagai golongan dapat mengurangi 'diskriminasi' dalam penegakan hukum.

Penalisasi dan kriminalisasi terhadap perbuatan yang termasuk WCC dapat mengubah citra hukum dan penegakannya selama ini yang lebih banyak ditegakkan pada kejabatankejahatan yang pelakunya golongan masyarakat biasa. Dengan ada WCC yang benar-benar ditegakkan melalui mekanisme hukum pidana membuka pikiran dalam beberapa hal: pertama, prinsip kesamaan di depan hukum yang merupakan prinsip dasar penyelenggaraan negara hukum benar-benar ditegakkan dan hukum berlaku untuk semua; kedua, merupakan dukungan sosial untuk menegakkan nilai-nilai sosial sekaligus menghidupkan mekanisme kontrol dalam masyarakat; ketiga, memberi orientasi baru terhadap masyarakat, karena merupakan kemunafikan jika kejahatan di kalangan bawah dipandang dengan rasa kebencian, sementara tipu muslihat yang dilakukan oleh kalangan atas 'dibenarkan'.

\section{Model Penyelesaian Perkara Pidana}

SETLAP pelanggaran hukum pidana diselesaikan melalui mekanisme yang diatur dalam Undang-undang Hukum Acara Pidana yang dikenal dengan Sistem Peradilan Pidana. Dalam prakteknya, tidak setiap pelanggaran hukum pidana diproses melalui Sistem Peradilan Pidana yang berakhir dengan penjatuhan pidana. Ada beberapa alasan terjadinya praktek penyelesaian perkara pidana di luar Sistem Peradilan Pidana:

Pertama, adanya pandangan bahwa penegakan hukum pidana akan selalu berakhir dengan penjatuhan pidana dan pidana selalu bersifat 'menderitakan' dan 'merugikan', maka perkara yang hendak diproses harus selektif dan bilamana dipandang perlu saja (asas subsidiaritas) dan merupakan alternatif pamungkas (ultimum remedium). Kedua, sering dihadapkan pada keadaan yang kontradiktif, yaitu antara kepastian hukum dan keadilan hukum. Ketiga adanya peraturan hukum yang membolehkan penyelesaian tidak melalui mekanisme Sistem Peradilan Pidana, yaitu kewenangan polisi untuk menyampingkan perkara pidana yang serba ringan ${ }^{12}$, kewenangan jaksa untuk menyampingkan perkara karena demi kepentingan umum ${ }^{13}$, demi kepentingan hukum ${ }^{14}$, ada alasan yang kuat untuk melakukan penghentian penuntutan ${ }^{15}$, dan pelanggaran yang hanya diancam dengan denda saja $^{16}$, dan adanya Lembaga Schikking dalam delik ekonomi.

Ada dua model penyelesaian pelanggaran hukum pidana, yaitu penyelesaian perkara melalui mekanisme sistem peradilan pidana yang dikenal dengan model kriminalisasi dan melalui mekanisme di luar sistem peradilan pidana yang dikenal dengan model musyawarah (perdamaian atau "cooperation").

Orientasi model kriminalisasi adalah pada pelaku pelanggar hukum pidana. Yang menjadi sasaran adalah bagaimana pelaku dapat dijatuhi pidana. Model kriminalisasi dibentuk pertama-tama melalui proses penetapan hukum pidana dan penegakan hukum pidana yang dimulai dari proses penyelidikan dan penyidikan dilakukan untuk menetapkan adatidaknya pelanggaran hukum pidana dan siapa yang dapat dipertanggung-jawabkan sehubungan dengan pelanggaran tersebut yang dilakukan oleh polisi, penuntutan dilakukan oleh jaksa, dan putusan pengadilan melalui proses persidangan oleh hakim dan pelaksanaan pidana (eksekusi). Pemrosesan pelanggar yang berakhir dengan penjatuhan pidana terhadap pelaku merupakan konsekuensi logis dari pelanggarannya dan sebagai faktor penekan agar supaya tidak mengulangi pelanggarannya serta peringatan bagi calon pelanggar potensial. Penjatuhan pidana mengandung daya cegah terhadap pelanggaran hukum pidana meliputi dua sasaran sekaligus, yaitu terhadap pelaku (special deterrence) dan terhadap 
masyarakat umum (general deterrence). Oleh karena itu, menurut van den Heuvel, model kriminalisasi sering juga disebut "deterrence system". ${ }^{17}$

Berbeda dengan model kriminalisasi, model musyawarah (perdamaian atau "cooperation") titik tekannya bukan pada bagaimana hukum ditegakkan terhadap pelaku melainkan pada bagaimana pelanggaran yang menimbulkan kerugian tersebut diselesaikan sehingga pelaku tidak melakukan perbuatan lagi dan kerugian yang ditimbulkan dapat dipulihkan kembali. Model musyawarah berusaha untuk mengkompromikan berbagai kepentingan yang terkait melalui upaya yang dianggap cocok dengan cara penyediaan pengganti kerugian atau insentif, atau dengan penggunaan sarana (hukum) administratif, atau dengan cara yang bersifat persuasif, misalnya dengan memberikan stimulasi agar supaya tidak terjadi pelanggaran, agar pelaku secara sadar atau sukarela melakukan tindakan preventif dan represif. Menurut van den Heuvel model ini disebut "compliance system". ${ }^{18} \mathrm{Jadi}$, orientasi model musyawarah adalah pelanggaran beserta akibatakibatnya.

Penyelesaian terhadap kejahatan yang tergolong WCC dapat ditempuh melalui gabungan antara dua model tersebut. ${ }^{19}$ Kapan ditempuh melalui kriminalisasi atau musyawarah sangat tergantung situasi dan kondisinya, apabila perbuatan tersebut sudah sampai pada tingkat 'membahayakan' dan 'merusak' tatanan kehidupan masyarakat, lebih tepat bila digunakan penyelesaian model kriminalisasi. Sebaliknya, apabila penyelesaian melalui kriminalisasi tidak membawa hasil yang maksimal dan justru kerugian yang ditimbulkan semakin luas, maka penyelesaian model musyawarah merupakan pilihan tepat.

Ada kelebihan dan kekurangan penyelesaian WCC melalui musyawarah dan kriminalisasi: pertama, ditinjau dari aspek hukum, model musyawarah kualitas hukumnya rendah karena tidak ditetapkan melalui mekanisme atau proses penetapan hukum dan model kriminalisasi kualitas hukumnya tinggi karena ditetapkan melalui prosedur yang diatur oleh hukum yaitu melalui Sistem Peradilan Pidana; kedua, model musyawarah aspek sosiologis dan humanisnya tinggi karena dasar pijaknya adalah kepercayaan (khusnudlan) dan pencegahan secara sukarela, sebaliknya model kriminalisasi aspek sosiologis dan humanisnya rendah karena dasar pijaknya adalah ketidak-percayaan (su'udlan) dan merupakan reaksi atau balas dendam yang dilakukan dengan cara paksaan; ketiga, tingkat efektivitas dan efisiensi model musyawarah sangat tinggi, sedang model kriminalisasi sangat rendah.

Kendatipun model musyawarah memiliki banyak kelebihan dibandingkan dengan model kriminalisasi dan merupakan alternatif penyelesaian yang terbaik terhadap kejahatan ekonomi yang termasuk WCC -- khususnya yang dilakukan oleh korporasi -- tetapi di sisi lain cara persuasif atau stimulasi terhadap pelanggar hukum -- apalagi pelanggar yang termasuk golongan masyarakat yang 'terhormat' dan 'terpandang', atau korporasi yang notabene memiliki kemampuan negosiasi yang sangat tinggi -- dapat berubah menjadi hubungan yang illegal, yaitu 'kong-kalikong' atau kolusi. Karena apabila pendekatan persuasif atau stimulus semakin kuat, maka mekanisme kontrol melalui sarana hukum pidana akan melemah, pada gilirannya menciptakan situasi yang kriminogen, dapat berbentuk penyalah- gunaan kekuasaan atau penyalahgunaan kepercayaan.

\section{Kendala Penyelesaian WCC Melalui Sistem Peradilan Pidana (Kriminalisasi)}

SEBAGAIMANA dikemukakan di bagian sebelumnya bahwa penyelenggaraan sistem peradilan pidana dimulai dari penetapan suatu perbuatan menjadi suatu perbuatan yang dilarang (kriminalisasi). Dalam penetapan kejahatan atau perbuatan yang dilarang dalam hukum pidana, Soedarto ${ }^{20}$ berpendapat, ada empat hal yang perlu dipertimbangkan: pertama, tujuan hukum pidana; kedua, penetapan perbuatan yang tidak dikehendaki; tiga, perbandingan antara sarana dan hasil, dan; ke empat, kemampuan badan penegak hukum.

Pelarangan suatu perbuatan dalam hukum pidana tidaklah mudah karena terkait dengan 
berbagai faktor yang lain yang bersifat nonhukum. Pada bidang-bidang tertentu hukum pidana berhubungan timbal-balik dengan bidang kehidupan lain, misalnya politik, ekonomi, sosial budaya dan bidang kehidupan lainnya. Faktor-faktor sosial yang mempengaruhi pembentukan hukum tersebut kadang- kadang sangat menentukan karakteristik hukum dan penegakan hukumnya. Kecepatan perkembangan bidang kehidupan, terutama bidang ekonomi, sulit untuk diprediksi melalui sarana hukum pidana, apalagi bidang hukum pidana terkait dengan asas legalitas yang mengharuskan adanya peraturan tertulis. Model hukum yang demikian ini cenderung tertinggal dari kehidupan sosial lainnya.

Problema hukum pidana dalam meng- antisipasi gelagat perkembangan kejahatan di bidang ekonomi adalah kesulitan memprediksi bentuk-bentuk penyimpangan yang akan terjadi di bidang ekonomi. Kendatipun bentuk-bentuk penyimpangan di bidang ekonomi secara umum (delik genusnya) telah diatur dalam hukum pidana, dalam prakteknya mengalami kendala sebagai berikut:

Pertama, polisi sulit mendeteksi terjadinya pelanggaran di bidang ekonomi. Usaha penyelidikan dan penyidikan tidak mampu mengungkap pelanggaran tersebut karena korbannya tidak kentara dan bersifat tidak langsung. $\mathrm{Da}-$ lam kasus tertentu korbannya tidak bisa bicara. Kejahatan tersebut terjadi terakumulasi dalam proses waktu yang cukup lama dan dilakukan secara terus-menerus.

Kedua, bentuk dan modus operandi kejahatan berubah terus-menerus sesuai dengan perkembangan teknologi dan perkembangan di bidang kegiatan ekonomi, sementara unit khusus yang memiliki keahlian untuk menangani kejahatan yang termasuk WCC masih sangat terbatas. Kejahatan di bidang ekonomi cenderung menggunakan modus operandi yang baru akibatnya polisi lebih banyak reaktif daripada bertindak pro-aktif.

Ketiga, pejabat penegak hukum merasa 'pekewuh' terhadap pelaku kejahatan. Pelaku WCC kadang menduduki jabatan terhormat di masyarakat dan mempunyai peran sosial yang tinggi serta memiliki posisi "bargaining" yang kuat. Dalam kasus-kasus tertentu, pelaku melakukan kolusi dengan pejabat penegak hukum itu sendiri sehingga pejabat hukum tidak memiliki kekuatan moral menindak pelaku kejahatan.

Keempat, pengumpulan bukti-bukti mengalami kesulitan dan memerlukan waktu yang relatif lama serta biaya yang mahal. Hal ini disebabkan karena kejahatan terjadi dan dilakukan secara terus-menerus. Bukti-bukti yang diperlukan sudah hilang atau berubah karena proses alam.

Kelima, pemberitaan pers, di samping merupakan sebagai "punishment" sendiri, dapat menjadi kendala proses penegakan hukum. Pemberitaan pers dapat memberi "informasi" dan kesempatan kepada pelaku menghilangkan bukti-bukti yang dipakai dalam melakukan kejahatan.

Keenam, tersangka atau penasihat hukumnya kadang lebih menguasai atau ahli/profesional menangani kasus karena pengalamannya menyelesaikan kasus-kasus lain yang sejenis.

Ketrujuh, penentuan pertanggung-jawaban pidana terhadap pelaku sangat sulit, karena subjek pelaku kejahatan dapat berbentuk badan hukum dan terorganisasi. Dalam hukum pidana, setiap pelaku hanya bertanggung-jawab terhadap kelakuan beserta akibat-akibatnya, sedangkan akibat dalam WCC sulit untuk dibuktikan kelakuan mana yang menimbulkan akibat yang dilarang dan siapa yang harus bertanggung-jawab. Dalam praktek, sering ditemukan kejahatan terjadi hasil dari akumulasi dari beberapa kelakuan oleh lebih dari satu subjek hukum. Akibatnya kesulitan untuk merekonstruksi bukti-bukti yang ada.

Kedelapan, pemidanaan berupa penjara sulit untuk diterapkan kepada pelaku WCC yang berbentuk korporasi, padahal pidana penjara merupakan pidana pokok yang menjadi standar pemidanaan sampai saat ini. Jika korporasi dijatuhi pidana penjara, ini berarti pihak-pihak yang tidak ikut melakukan atau bertanggung-jawab akan menderita kerugian atau menanggung risiko. Tetapi apabila hanya pidana denda yang dijatuhkan akan menim- 
bulkan perlakuan yang tidak adil, karena pelanggaran yang sama yang dilakukan oleh pelaku non-korporasi dijatuhi pidana penjara.

\section{Kesimpulan}

PENGGOLONGAN ke dalam berbagai bentuk kejahatan, misalnya "white-collar crime", "organized crime", "street crime" dan sejenisnya merupakan hasil kajian dari bidang studi sosiologi dan kriminologi, bukan penamaan dari peraturan hukum pidana. Penamaan suatu kejahatan menjadi "white-collar crime" di satu sisi memberi dampak positif terhadap proses penegakan hukum, di sisi yang lain menimbulkan dampak negatif karena seolah-olah terjadi diskriminasi dalam proses penegakan hukum.

Kejahatan yang termasuk "white-collar crime" lebih efektif penyelesaiannya apabila ditempuh melalui sistem musyawarà (cooperation) daripada melalui proses peradilan pidana (kriminalisasi). Sungguhpun demikian, penyelesaian kejahatan melahi sistem musyawarah cenderung menciptakan terjadinya pelanggaran (kejahatan) baru yang disebut dengan kolusi dapat berbentuk penyalahgunaan wewenang atau penyalahgunaan kepercayaan. Sebaliknya, penyelesaian melalui proses peradilan pidana (kriminalisasi) yang merupakan mekanisme penyelesaian perkata pidana yang resmi tidak selalu menghasilkan suatu yang positif dan menyelesaikan masalah yang ditimbulkan WCC, karena menghadapi kendala yang bersumber dari aturan hukum pidana, kemampuan aparat penegak hukum, dan proses penentuan pertanggung-jawaban pidana selanjutnya.

Selanjutnya, segala bentuk kejahatan akan berubah bentuk sesuai dengan pola kehidupan masyarakatnya, maka kemampuan pembentuk hukum dan penegak hukum untuk memprediksi kecenderungan perilaku ekonomi yang negatif dalam masyarakat merupakan "treatment" yang terbaik guna menghindari "adanya kerugian-kerugian yang lebih besar yang bersifat "destructive" tatanan kehidupan masyarakat.
Mudzakkir, SH, MH, adalah staf pengajar pada FH UII. Jenjang S-1 diperoleh dari Fak. Hukam UII, dan jenjang $S-2$ pada Universitas Indonesia.

\section{Catatan Kaki:}

1. Selanjutnya disingkat WCC.

2. Artinya, bentuk perbuatannya sebagian besar telah diatur dalam berbagai peraturan hukum pidana yang kemudian dipandang perlu untuk diselesaikan melalui mekanisme hukum pidana (penalisasi), dan sebagian di antaranya karena adanya proses kriminalisasi.

3. Muhammad Mustofa, "Kejahatan Korporasi", Laporan Penelitian, Jakarta: Pusat Pelayanan Keadilan dan Pengabdian Hukum, Universitas Indonesia, 1983, hlm. 14.

4. Kata "penyelesaian" ini memiliki arti yang luas, yaitu penyelesaian secara hukum melalui mekanisme sistem peradilan pidana dan penyelesaian dengan cara lain yang tidak melalui mekanisme sistem peradilan pidana. Bentuk penyelesaian yang terakhir ini dibedakan yang positif karena adanya iktikad baik dan alasanalasan yang dibenarkan oleh hukum, dan yang negatif karena termasuk perbuatan yang melawan hukum.

5. Moeljatno, Azas-azas Hukam Pidana, Yogyakarta: Universitas Gadjah Mada, tanpa tahun, him. 5.

6. James P. Levine, Machael C. Musheno, dan Dennis J. Palumbo, Criminal and Justice: $A$ Public Policy Approach, New York: Harcourt Brace Jovanovich, Inc., 1980, hlm. 82-109.

7. Larry J. Siegel, Criminology, New York: West Publishing Company, 1986, hlm. 288-435.

8. Ibid.

9. Ibid.

10. Muhammad Mustofa, Op. Cit, hlm. 10.

11. Ibid.

12. Lihat penjelasan umum Undang-undang Nomor 13 Tahun 1961 tentang Ketentuanketentuan Pokok Kepolisian.

13. KUHAP Pasal 46 ayat (1) huruf $c$ jo Undangundang Nomor 32 Tahun 1991 tentang Kejaksaan Republik Indonesia, Pasal 32 huruf $c$.

14. KUHAP Pasal 14 huruf $h$.

15. KUHAP Pasal 140 Ayat (2) huruf a.

16. KUHAP Pasal 82.

17. G.A.A.J. van den Hauvel, "Corporate Crimes From an International Perspective", Makalah disampaikan pada Seminar Kriminologi VI, Semarang, 16-18 September 1991, hlm. 1. 
18. Ibid. Satu perbuatan melawan hukum dalam hukum pidana sebenarnya dapat dikenakan dengan berbagai macam pelanggaran hukum lain yang non-hukum pidana, misalnya hukum perdata atau hukum administrasi.

19. Satu perbuatan melawan hukum dalam hukum pidana. sebenarnya dapat dikenakan dengan berbagai macam pelanggaran hukum lain yang non-hukum pidana, misalnya hukum perdata atau hukum administrasi. Karena salah satu fungsi hukum pidana dalam kaitannya dengan bidang hukum lainnya adalah memperkuat berlaku norma hukum lain.

20. Soedarto, Hukum dan Hukum Pidana, Bandung: Alumni, 1986, hlm. 36. 